\title{
Fungsi Seksual Pada Akseptor Kontrasepsi Hormonal Depo Medroxyprogesterone Acetate
}

\author{
Sexual Function In Acceptors of Depo Medroxyprogesterone Acetate \\ Hormonal Contraception
}

\author{
Farida Yuliani $^{1}$, Fitria Edni Wari ${ }^{2}$, Ferilia Adiesti ${ }^{3}$, Nurun Ayati Khasanah ${ }^{4}$ \\ 1,2,3,4 Program Studi Kebidanan Sekolah Tinggi Ilmu Kesehatan Majapahit \\ 1Email : yulianif686@gmail.com
}

\begin{abstract}
ABSTRAK
Perubahan hormonal akibat penggunaan kontrasepsi hormonal diketahui menjadi salah satu penyebab disfungsi sexual. Gangguan fungsi seksual dapat mempengaruhi kemampuan untuk membangun dan mempertahankan hubungan intim dengan pasangan, dan mengganggu kesehatan mental seperti kecemasan dan depresi. Penelitian deskriptif ini menggunakan desain Cross Sectional bertujuan untuk mengetahui gambaran fungsi seksual akseptor kontrasepsi hormonal Depo Medroxyprogesterone Acetate (DMPA). Populasi penelitian ini adalah wanita yang menggunakan kontrasepsi hormonal DMPA. Pemilihan sampel dilakukan secara total sampling. Pengumpulan data menggunakan kuesioner Female Sexual Function Index (FSFI) selanjutnya data ditabulasi dan dianalisis secara deskriptif. Hasil penelitian menunjukkan bahwa sebagian besar akseptor kontrasepsi DMPA mengalami disfungsi seksual dan sebagian besar akseptor sudah $\geq 2$ tahun menggunakan kontrasepsi hormonal DMPA. Efek hipo estrogenik sistemik DMPA ini menyebabkan mukosa vagina atrofi, kekeringan vagina dan dispareunia sehingga menyebabkan gangguan fungsi seksual. Bidan sebagai pemberi pelayanan kesehatan perlu melakukan diskusi secara terbuka dengan akseptor kontrasepsi hormonal terkait fungsi seksual mereka sehingga akseptor kontrasepsi tetap menggunakan kontrasepsi efektif untuk mencegah kehamilan dan tetap memberi dukungan secara emosional dan seksual di kehidupan seorang wanita.
\end{abstract}

Kata kunci : Fungsi Seksual, Akseptor, DMPA

\section{ABSTRACT}

Hormonal changes due to the use of hormonal contraceptives are known to be one of the causes of sexual dysfunction. Impaired sexual function can affect the ability to establish and maintain intimate relationships with a partner, and interfere with mental health such as anxiety and depression. This descriptive study using a cross-sectional design aims to describe the sexual function of acceptors of hormonal contraception Depo Medroxyprogesterone Acetate (DMPA). The population of this study was women who used DMPA hormonal contraception. Sample selection is done by total sampling. The data was collected using the Female Sexual Function Index (FSFI) questionnaire, then the data were tabulated and analyzed descriptively. The results showed that most of the DMPA contraceptive acceptors experienced sexual dysfunction and most of the acceptors had used DMPA hormonal contraception for 2 years. DMPA's systemic hypo-estrogenic effect causes vaginal mucosal atrophy, vaginal dryness, and dyspareunia, causing sexual dysfunction. Midwives as health care providers need to have open discussions with hormonal contraceptive acceptors regarding their sexual function so that contraceptive acceptors continue to use effective contraception to prevent pregnancy and continue to provide emotional and sexual support in a woman's life.

Keywords: Sexual Function, Acceptor, DMPA

\section{PENDAHULUAN}

Seks menjadi aspek penting dalam kualitas hidup seseorang yang dapat mempengaruhi beberapa aspek seperti fisik dan psikologis (Ozgoli $d k k$., 2015). Kepuasan seksual berperan 
dalam peningkatan kesehatan dan kualitas hidup seorang wanita. Adanya disfungsi seksual dapat mempengaruhi kemampuan untuk membangun dan mempertahankan hubungan intim dengan pasangan, dan mengganggu kesehatan mental seperti kecemasan dan depresi (Djami $d k k ., 2018$ ).

Disfungsi seksual merupakan masalah yang sering terjadi pada wanita, salah satu penyebab gangguan ini adalah karena perubahan hormon yang bisa disebabkan oleh kontrasepsi hormonal. Kontrasepsi hormonal yang paling umum digunakan di Indonesia adalah kontrasepsi suntik, baik bulanan atau setiap tiga bulan (Lubis $d k k$., 2018). Kontrasepsi suntik menjadi pilihan yang aman dan efektif untuk mencegah kehamilan yang tidak diinginkan. Saat ini, ada dua jenis kontrasepsi yang tersedia, progestin yaitu Depo Medroxyprogesterone Acetate (DMPA) dan kontrasepsi kombinasi. Senyawa progestin sangat efisien, tetapi memiliki efek samping yang signifikan. Ini sama efektifnya dengan sterilisasi, dan lebih efektif daripada metode kontrasepsi oral dan barrier (Ozgoli $d k k ., 2015)$.

Pada tahun 2018 sekitar 24,25 juta pasangan usia subur yang mengikuti kepesertaan keluarga berencana (KB) dari 38,34 juta jumlah pasangan usia subur di Indonesia. Metode kontrasepsi yang paling umum digunakan adalah kontrasepsi suntik (63,71\%), pil (17,24\%), IUD (7,35\%), implant $(7,20)$, MOW (2,76 \%), MOP $(0,50 \%)$ dan kondom $(1,24 \%)$ (Kementerian Kesehatan RI, 2018). Data tersebut menunjukkan kontrasepsi suntik lebih banyak di gunakan oleh pasangan usia subur di Indonesia. Data jumlah kejadian disfungsi seksual pada wanita di Indonesia sampai saat ini masih belum dapat dipastikan.

Berdasarkan penelitian Aisyah (2015), jumlah akseptor KB suntik 3 bulan selama lebih dari 2 tahun adalah 54 orang, mengalami perubahan libido sebesar $59,7 \%$, berjumlah 46 orang dan 8 orang tidak mengalami perubahan (Ernawati, Alfiah dan Askar, 2019).

Hormon seks seperti estrogen dan progesteron dapat memberikan efek berbeda pada perilaku dan fungsi seksual wanita dengan cara mempengaruhi jaringan vagina dan sistem saraf pusat. Menurut literatur, hormon yang digunakan dalam metode kontrasepsi memiliki efek kontradiktif pada fungsi seksual wanita pada usia reproduksi (Kariman dkk., 2017). 
Mengingat dampak jangka panjang dari kontrasepsi, pemenuhan aspek etika harus dipastikan untuk setiap pilihan yang diambil (Djami $d k k ., 2018)$. Efek negatif kontrasepsi hormonal DMPA yang dilaporkan pada fungsi seksual ditunjukkan dalam beberapa penelitian. Mekanisme kerja kontrasepsi hormonal DMPA adalah dengan menekan sekresi gonadotropin. Penurunan hormon luteinisasi menghasilkan penghambatan ovulasi, sedangkan penurunan hormon perangsang folikel menghasilkan keadaan hipoestrogenik sistemik. Dalam penggunaan kontrasepsi hormonal DMPA jangka panjang, perubahan atrofi endometrium dan atrofi mukosa vagina ditunjukkan dalam beberapa penelitian. Atrofi mukosa vagina dan kekeringan pada vagina dapat menyebabkan nyeri seksual atau dyspareunia (Kariman $d k k$., 2017). Satu studi tentang pengguna kontrasepsi hormonal DMPA menemukan bukti terjadi penurunan libido pada sekitar 1 dari 4 pengguna yang kembali untuk injeksi kedua setelah tiga bulan (Umran, 2016; Sigei, 2020). Pada penelitian ini peneliti tertarik untuk mengetahui bagaimana fungsi seksual akseptor kontrasepsi hormonal DMPA.

\section{METODE PENELITIAN}

Penelitian ini merupakan penelitian deskriptif dengan desain Cross Sectional yang dilaksanakan di BPM Farida Yuliani, M.Kes. Populasi penelitian ini adalah wanita yang menggunakan kontrasepsi hormonal DMPA. Subyek penelitian adalah populasi yang berkunjung KB di PMB Farida Yuliani, M.Kes untuk mendapatkan kontrasepsi hormonal DMPA. Pemilihan sampel penelitian dilakukan secara total sampling. Wanita yang memenuhi syarat menurut kriteria inklusi diberikan informed consent. Subyek kemudian mengisi kuesioner Female Sexual Function Index (FSFI) dan data ditabulasi dan dievaluasi kembali. Data karakteristik dianalisis secara deskriptif. Skoring ditentukan dari jawaban setiap pertanyaan dari kuesioner FSFI yang telah diisi kemudian ditentukan jenis dan fungsi seksual masing-masing subjek. Fungsi seksual dikategorikan menjadi dua, normal jika skor FSFI $\geq 26,55$ dan disfungsi seksual jika skor FSFI < 26,55 . 
HASIL DAN PEMBAHASAN

Tabel 1. Distribusi Frekuensi Responden Berdasarkan Usia

\begin{tabular}{lcc}
\hline Usia (Tahun) & Frekuensi & Persentase \\
\hline $25-35$ & 13 & 39,4 \\
$36-45$ & 15 & 45,5 \\
$46-55$ & 5 & 15,2 \\
\hline Total & 33 & 100 \\
\hline
\end{tabular}

Tabel 2. Distribusi Frekuensi Responden Berdasarkan Pendidikan

\begin{tabular}{lcc}
\hline Pendidikan & Frekuensi & Persentase \\
\hline Dasar & 7 & 51,5 \\
Menengah & 13 & 39,4 \\
Tinggi & 3 & 9,1 \\
\hline Total & 33 & 100 \\
\hline
\end{tabular}

Tabel 3. Distribusi Frekuensi Responden Berdasarkan Paritas

\begin{tabular}{lcc}
\hline Paritas & Frekuensi & Persentase \\
\hline Primipara & 10 & 30,3 \\
Multipara & 23 & 69,7 \\
\hline Total & 33 & 100 \\
\hline
\end{tabular}

Tabel 4. Distribusi Frekuensi Responden Berdasarkan Lama Menggunakan

Kontrasepsi

\begin{tabular}{lcc}
\hline Lama & Frekuensi & Persentase \\
\hline$<2$ tahun & 3 & 9,1 \\
$\geq 2$ tahun & 30 & 90,9 \\
\hline Total & 33 & 100 \\
\hline
\end{tabular}

Berdasarkan tabel 4. Sebagian besar responden $30(90,9 \%)$ sudah $\geq 2$ tahun menggunakan kontrasepsi DMPA dan sebagian kecil $3 \quad(9,1 \%)$ menggunakan kontrasepsi DMPA kurang dari 2 tahun.
Tabel 5. Distribusi Frekuensi Responden Berdasarkan Fungsi Seksual

\begin{tabular}{lcc}
\hline Fungsi Seksual & Frekuensi & Persentase \\
\hline Normal & 4 & 12,1 \\
Disfungsi & 29 & 87,9 \\
Seksual & & \\
\hline Total & 33 & 100 \\
\hline
\end{tabular}

Berdasarkan tabel 5. Sebagian besar responden $29(87,9 \%)$ mengalami disfungsi seksual dan sebagian kecil 4 $(12,1 \%)$ tidak mengalami disfungsi seksual atau dalam kategori normal.

Kontrasepsi hormonal dapat mempengaruhi fungsi seksual wanita baik secara positif maupun negatif. Berdasarkan hasil penelitian menunjukkan bahwa sebagian besar akseptor kontrasepsi hormonal DMPA mengalami disfungsi seksual dan sebagian besar akseptor sudah $\geq 2$ tahun menggunakan kontrasepsi hormonal DMPA. Fungsi seksual merupakan respons kompleks fisik dan emosional yang dikoordinasikan oleh sistem neurologis, vaskular, dan hormonal. Ini adalah salah satu komponen penting dalam kehidupan keluarga dan fungsi seksual pasangan yang menggunakan metode kontrasepsi hormonal DMPA. Ketika disfungsi seksual terjadi pada individu, dampak buruk pada kesehatan mental, harga diri, penolakan sosial, hubungan interpersonal dan masalah 
pernikahan sering terjadi (Umran, 2016). Beberapa faktor termasuk penuaan, status kesehatan, hormon, pengalaman pribadi, stres, kondisi budaya, keyakinan agama, dan hubungan pasangan mempengaruhi fungsi seksual. Masalah pada satu atau lebih faktor di atas dapat menyebabkan disfungsi seksual. Dalam pemberian layanan keluarga berencana, kemungkinan efek dari metode kontrasepsi pada fungsi seksual dan kehidupan seksual harus dipertimbangkan (Saptatangtrakun $d k k$., 2016).

Mekanisme kerja DMPA adalah supresi sekresi gonadotropin. Ketika terjadi supresi sekresi gonadotropin, penurunan hormon luteinisasi menghasilkan penghambatan ovulasi sedangkan penurunan hormon perangsang folikel menyebabkan keadaan hipo estrogenik sistemik. Efek hipo estrogenik sistemik DMPA ini menyebabkan mukosa vagina atrofi, kekeringan vagina dan dispareunia (Sigei, 2020).

Beberapa aspek fungsi seksual pada seorang wanita meliputi; keinginan atau keinginan untuk aktivitas seksual, kemampuannya untuk memulai dan mempertahankan gairah, pelumasan yang cukup, mengalami orgasme, menikmati sensasi aktivitas seksual yang sebenarnya dan meminimalkan rasa sakit dan ketidaknyamanan seksual.

Obesitas, flek dan keterlambatan kembalinya kesuburan secara psikologis dapat mempengaruhi wanita sehingga mempengaruhi aktivitas seksual. Sebuah penelitian yang dilakukan oleh Saptatangtrakul Y, et al. Ketika fungsi seksual individu diamati pada wanita yang menggunakan DMPA, prevalensi disfungsi seksual tertinggi ditemukan pada hasrat seksual diikuti oleh gairah dan orgasme (Saptatangtrakun $d k k$., 2016).

Dalam sebuah penelitian yang dilakukan oleh Casey, frekuensi aktivitas seksual dan kenikmatan seksual berkorelasi positif dengan kepuasan kontrasepsi. Berkurangnya fungsi seksual yang penyebabnya terkait dengan penggunaan kontrasepsi dapat menyebabkan penurunan angka penggunaan kontrasepsi yang efektif sehingga dapat meningkatkan kehamilan yang tidak diinginkan (Sigei, 2020). Penerimaan penggunaan alat kontrasepsi pada saat ini tidak hanya terbatas pada ada atau tidak adanya efek samping tetapi juga pada kualitas kehidupan seksual (Casey, 
MacLaughlin dan Faubion, 2017).

Perempuan harus dibantu untuk memilih alat kontrasepsi yang tidak hanya efektif dalam mencegah kehamilan tetapi juga ramah secara emosional dan seksual dengan kehidupan mereka (Kariman $d k k$., 2017).

Beberapa efek samping penggunaan kontrasepsi hormonal mempengaruhi fungsi seksual akseptor seperti perubahan menstruasi, kenaikan berat badan yang dialami oleh akseptor. Perubahan menstruasi dapat mempengaruhi ekspresi seksual wanita baik secara positif jika perdarahan berkurang atau negatif jika terjadi perdarahan yang meningkat atau tidak terduga. Beberapa wanita di beberapa budaya atau agama akan menghindari hubungan seks melalui vagina atau kontak genital lainnya saat mereka mengalami menstruasi atau spotting. Bila ini terjadi, akan mengakibatkan berkurangnya minat berhubungan seks dan satu-satunya cara adalah dengan menghentikan metode tersebut (Sigei, 2020).

Kenaikan berat badan pada pengguna kontrasepsi hormonal DMPA kemungkinan lebih disebabkan oleh metode kontrasepsi mereka daripada faktor gaya hidup dan jika wanita tidak nyaman dengan tubuhnya dapat mengganggu kemampuannya untuk merasa diinginkan dan menikmati seks (Sigei, 2020). Perasaan wanita pada berat badannya sangat penting dan kepuasan dengan tubuh seseorang sangat terkait dengan hasil yang berhubungan dengan seksualitas daripada ukuran tubuh yang sebenarnya. Demikian pula perubahan seksual negatif cenderung dikaitkan dengan hubungan, stres hidup, kesehatan atau faktor eksternal lainnya (Higgins dan Davis, 2014).

Penggunaan kontrasepsi hormonal DMPA selama 12 sampai 24 bulan dapat menyebabkan terjadinya penurunan kadar estradiol serum yang juga dapat mempengaruhi hasrat seksual, selain itu pemakaian kontrasepsi hormonal DMPA dalam waktu lama menyebabkan penurunan kadar estrogen dan estradiol serum yang menyebabkan menurunnya fungsi seksual wanita (Isfaizah dan Widyaningsih, 2019). 


\section{SIMPULAN DAN SARAN}

$\begin{array}{lrr}\text { Sebagian } & \text { besar akseptor } \\ \text { kontrasepsi } & \text { hormonal } & \text { Depo }\end{array}$ Medroxyprogesterone Acetate (DMPA) mengalami disfungsi seksual. Bidan sebagai pemberi pelayanan kesehatan perlu melakukan diskusi dengan akseptor kontrasepsi hormonal tentang fungsi seksual akseptor sehingga akseptor kontrasepsi tetap bisa menggunakan kontrasepsi yang efektif dalam pencegahan dan pengaturan jarak kehamilan serta tetap mendukung secara emosional dan seksual pada kehidupan seorang wanita. Bidan berada dibawah naungan puskesmas maka penyampaian hasil kajian ilmiah tentang disfungsi social perlu disampaikan pada instansi kesehatan terkait agar bisa dilakukan penyelesaian ataupun pemberian solusi guna menangani disfungsi seksual sehingga masyarakat merasakan maafaat sehubungan dengan masalah disfungsi seksual.

\section{DAFTAR PUSTAKA}

Casey, P. M., MacLaughlin, K. L. dan Faubion, S. S. (2017) "Impact of contraception on female sexual function," Journal of Women's Health. Mary Ann Liebert, Inc. 140 Huguenot Street, 3rd Floor New Rochelle, NY 10801 USA, 26(3), hal. 207-213.
Djami, M. E. U. $d k k$. (2018) "Sexual function of depot medroxyprogesterone acetate users," Journal of South India Medicolegal Association, 10(2), hal. $108 . \quad$ doi: 10.5281/zenodo.1462146.

Ernawati, E., Alfiah, A. dan Askar, M. (2019) "The Relation Of Length Of Use The Injected Contraception With Sexuality On Fertile Women In Coverage Area Of Puskesmas Caile, Bulukumba, Indonesia," Prosiding, 2(1).

Higgins, J. A. dan Davis, A. R. (2014) "Contraceptive sex acceptability: a commentary, synopsis and agenda for future research," Contraception. Elsevier, 90(1), hal. 4-10.

Isfaizah, I. dan Widyaningsih, A. (2019) "Hubungan Penggunaan Kontrasepsi Hormonal dengan Disfungsi Seksual di Wilayah Kerja Puskesmas Lerep," Indonesian Journal of Midwifery (IJM), 2(2), hal. 64-71. doi: 10.35473/ijm.v2i2.270.

Kariman, N. dkk. (2017) "Sexual Dysfunction in Two Types of Hormonal Contraception: Combined Oral Contraceptives versus Depot Medroxyprogesterone Acetate," Journal Midwifery \& Reproductive Health, 5(1), hal. 806-813. doi: 10.22038/jmrh.2016.7763.

Kementerian Kesehatan RI (2018) "Laporan Hasil Riset Kesehatan Dasar (Riskesdas) Indonesia tahun 2018," Riset Kesehatan Dasar 2018, hal. 182-183. 
Lubis, Q. A. dkk. (2018) "Female Sexual Function in DMPA and Cyclofem," 17(10), hal. 76-81. doi: 10.9790/0853-1710067681.

Ozgoli, G. $d k k$. (2015) "Comparison of sexual dysfunction in women using depo-Medroxyprogesterone acetate (DMPA) and Cyclofem," Journal of Reproduction and Infertility, 16(2), hal. 90-95.

Saptatangtrakun, Y.dkk. (2016) "Sexual Function in Women Using DMPA Injection and Copper Intrauterine Device," Thai Journal of Obstetrics and Gynaecology, 24(4), hal. 294-301.
Sigei, L. C. (2020) "Sexual function and quality of life of women using Medroxyprogesterone Acetate contraceptive in Nakuru County Referral Hospital.” Moi University.

Umran, O. (2016) "Effect of the Contraceptive Methods on Female Sexual Function," International Journal of Caring Sciences, 9(3), hal. 997. 